\title{
A COMPARATIVE STUDY ON BIOCHEMICAL PARAMETERS FOR MATURE CALIFORNIA AND CHINCHILLA RABBITS IN SOHAG GOVERNORATE.
}

\section{Gehad Seddik $^{1}$, Ahmed A.Aboughaba ${ }^{3}$, Fatma A, Mahmoud ${ }^{1}$, Doaa Salman ${ }^{2}$ and Motamed E. Mahmoud ${ }^{*}$}

\author{
${ }^{1}$ Department of Animal Behavior and Husbandry, Faculty of Veterinary Medicine, Sohag University, Egypt. \\ ${ }^{2}$ Department of Animal Medicine, Faculty of Veterinary Medicine, Sohag University, Egypt. \\ ${ }^{3}$ Department of Poultry Production, Faculty of Veterinary Medicine, Sohag University, Egypt. \\ * Corresponding author's email; motamed71111@gmail.com
}

\begin{abstract}
Rabbit as homeothermic species is able to keep its core body temperature within $\pm 1^{\circ} \mathrm{C}$ regulatory range. In Upper Egypt where high ambient temperature particularly at summer months, rabbit breeding ceases, by virtue of its fur, there is certain inability to dissipate excess body heat. Under uncontrolled ambient environment, most of the observed mortality at summer is due to heat stasis. In this study, we compared white (California) to black (Chinchilla) mature breeds of rabbits. Blood picture and serum hormonal profiles were assessed. The results showed many similarities between the two breeds in terms of blood picture, the serum concentration of tri-iodothyronine (T3) and thyroxine (T4), but T3/T4 ratio was higher and corticosterone was lower in California than Chinchilla rabbits $(P<0.5)$. Heat loss was higher in male California than other rabbits. The overall results referred to the higher ability of California breed to withstand heat stress compared to Chinchilla rabbits.
\end{abstract}

Original Article:

DOI:https://dx.doi.org/10.2160 8/javs.2019.62677

Received 03 April, 2019.

Accepted 28 April, 2019.

Published in April, 2019.

This is an open access article under the term of the Creative Commons Attribution 4.0 (CC-BY) International License. To view a copy of this license, visi http://creativecommons.org/licens es/by/4.0/

J. Appl. Vet. Sci., 4(1): 43-47.

Keywords: California, Chinchilla Rabbits, blood picture, corticosterone, $\mathrm{T}_{4}, \mathrm{~T}_{3}$.

\section{INTRODUCTION}

Rabbit breeding is gaining importance as a producer of meat, wool, and fur because of its prolificacy and higher feed conversion efficiency. Firstly New Zealand White rabbit was imported to Egypt, followed by import of Grey Giant, White Giant, and Soviet Chinchilla to breed them in temperate and sub-temperate conditions of the country. Crossbreeding has been established as breeding systems to exploit the heterosis in animal breeding and it could be fruitfully employed in rabbit breeding for increased productivity. However, in Upper Egypt high ambient temperature in summer months is considered the main threat to the industry. Besides the inability to reproduce, high mortalities are annually recorded.

Rabbit as mammalian species is able to keep its body temperature within a narrow balance range $\left( \pm 1^{\circ} \mathrm{C}\right)$ even when exposed to a vast range of external temperatures (Romanovsky, 2007). At high ambient temperature, heat production decreases while heat dissipation kept high. The resultant level of skin temperature depends on the rate of heat loss and the rate of gain from warm blood flows to the skin.
Therefore, the skin temperature could give an indication to the response of thermoregulation (Nääs $\boldsymbol{e t}$ al., 2010).

Biochemical and hematological examinations provide valuable information on an objective assessment of health status, in order to detect health disorders and monitoring stress factors already at the preclinical stage (Hinton et al., 1982). Changes in physiological biochemical and hematological values can also be used as indicators of welfare in rabbit breeding (Hoy and Verga 2006). Biochemical and hematological values may be influenced by a number of environmental factors, such as feed components and animal management. Differences between rabbit genotypes in biochemical and hematological values were studied in details in Watanabe heritable hyperlipaemic rabbits (Kurosawa et al., 1995).

In vertebrates, a central component of the stress response is the activation of the hypothalamicpituitary-adrenal (HPA) axis. The main glucocorticoid in humans is cortisol and corticosterone in birds and rabbit (Lewis et al., 2005). Thyroid hormones are hormones produced and released by the thyroid gland, 
namely triiodothyronine $\left(\mathrm{T}_{3}\right)$ and thyroxine $\left(\mathrm{T}_{4}\right)$. Although, the major form of thyroid hormone in the blood is thyroxine $\left(\mathrm{T}_{4}\right)$, which has a longer half-life than $T_{3}$. (Pilo et al., 1990), $T_{3}$ is the active form (3-4 times more potent than $\mathrm{T}_{4}$ ). The most common method for quantification of hormones such as corticosterone is enzyme-linked immunosorbent assay (ELISA) (Abelson et al., 2016). The work aimed to investigate and compare blood biochemical parameters in two divergent strains of rabbits (black and white) after inbreeding to the $5^{\text {th }}$ generation.

\section{MATERIALS AND METHODS}

\section{Animals}

This study applied on the $6^{\text {th }}$ generation of two breeds of rabbits; Chinchilla and California. Twentyeight mature rabbits (male and female), their age (1618 months) used for breeding at the experimental farm of Department of Animal Behavior and Husbandry, Veterinary Hospital, Faculty of Veterinary medicine, Sohag University. Each breed was kept in an isolated battery under a specific managemental program. e.g. Feeding, watering, utensils disinfection and vaccination.

\section{Environmental condition}

Ambient Temperature and relative humidity were measured by mini data-logger (testo $174 \mathrm{H}$; Germany) which record data every $30 \mathrm{~min} / 6000$ reading. Heat loss index was calculated from the measurement of ambient (Ta), skin (Ts) and body temperature $(\mathrm{Tb})$ according to formula; HLI $=$ Tsk$(\mathrm{Ta}) /(\mathrm{Tb})-(\mathrm{Ta})$. (Mahmoud et al., 2011) HLI value ranges theoretically from zero equivalents to the state of complete vasoconstriction to one (state of complete vasodilatation, Steiner and Branco, 2002).

\section{Sampling and analysis}

About $2 \mathrm{ml}$ of blood samples were collected from rabbits (from marginal and central ear vein) and divided to two portions; one part on EDTA tubes for blood picture and examined by eos vet analyzer (CBC Analyzer, Domnarvsgatan 4, SE-163 53 Spanga, Sweden). The other portion serum samples were obtained by centrifugation of blood samples at 5000 rpm for $15 \mathrm{~min}$ and then plasma transferred to clean Eppendorf tubes and kept in -20C until hormonal analysis. Serum corticosterone, $\mathrm{T}_{3}$ and $\mathrm{T}_{4}$ assays were performed according to Manufacturer Company (Assay pro LLC 3400 Harry S Truman Blvd St. Charles, USA).

\section{Statistical Analysis}

All analyses were performed by one wayANOVA and Tukey's post hoc tests using GraphPad Prism software ( $P$ was significant if $<0.05$ ). All data were represented as mean \pm SD

RESULTS

\begin{tabular}{|lccc|}
\hline \multicolumn{2}{|c|}{ Instrument Name: Sohag University } & \multicolumn{2}{c|}{$10: 57: 53$ 04/04/2019 } \\
\hline \multicolumn{2}{|c|}{ Start time: 03/01/2019 08:30:00 PM } & Minimum & Maximum \\
\hline End time: 04/04/2019 11:00:00 AM & Tempreture $\left[{ }^{\circ} \mathrm{C}\right]$ & 9.7 & 31.3 \\
\hline Measurement channels: 2 & Humidity $[\% \mathrm{rH}]$ & 23.3 & 74.4 \\
\hline
\end{tabular}

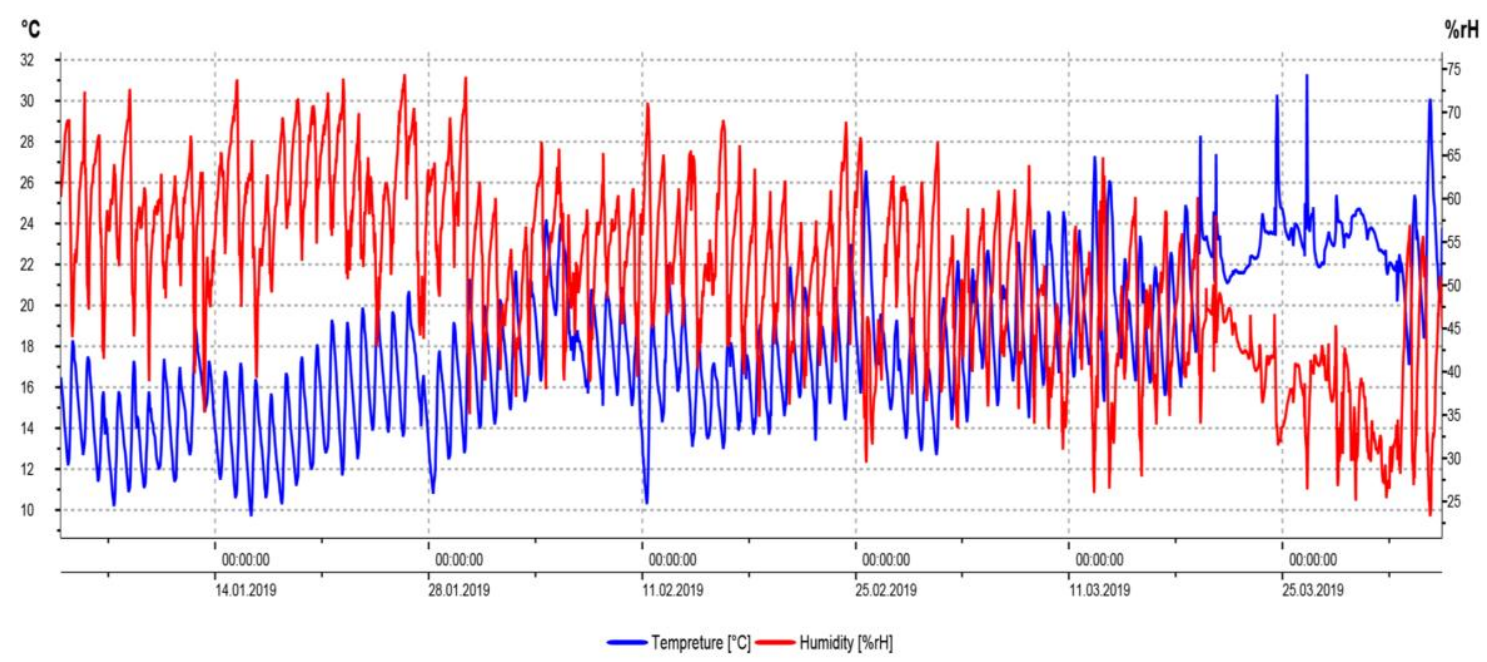

Fig. 1. Continuous measurement of temperature and relative humidity (from Jan. to March 2019). data logger was adjusted for taking the readings at 30 min interval 
Motamed E. Mahmoud et al...

Table1. Physiological parameters for California and Chinchilla rabbits (body weight, respiratory rate, and temperature):

\begin{tabular}{|c|c|c|c|c|c|}
\hline Parameter & $\begin{array}{c}\text { California } \\
\text { Female }\end{array}$ & $\begin{array}{l}\text { Californi } \\
\text { a Male }\end{array}$ & $\begin{array}{c}\text { Chinchilla } \\
\text { Female }\end{array}$ & $\begin{array}{c}\text { Chinchilla } \\
\text { Male }\end{array}$ & $P$ \\
\hline Weight (kg) & $2.75 \pm 0.1$ & $2.7 \pm 0.2$ & $3.0 \pm 0.4$ & $3.0 \pm 0.5$ & 0.03 \\
\hline $\begin{array}{l}\text { Respiratory rate } \\
\text { (n/15 Sec) }\end{array}$ & $23.8 \pm 1.6$ & $23.2 \pm 1.2$ & $19.0 \pm 1.1$ & $20.8 \pm 1.4$ & 0.07 \\
\hline $\begin{array}{l}\text { Rectal tempreture } \\
\left({ }^{\circ} \mathrm{C}\right)\end{array}$ & $39.0 \pm 0.5 \mathrm{a}$ & $39.0 \pm 0.5 \mathrm{a}$ & $39.3 \pm 0.4 \mathrm{a}$ & $39.9 \pm 0.4 \mathrm{~b}$ & 0.68 \\
\hline HLI at neck & $0.82 \pm 0.04 a$ & $1.0 \pm 0.03 b$ & $0.85 \pm 0.05 a$ & $0.81 \pm 0.04 a$ & 0.02 \\
\hline Ll at ea & $0.96 \pm 0.06$ & $0.93 \pm 0.04$ & $1.0 \pm 0.04$ & $0.92 \pm 0.08$ & 0.29 \\
\hline
\end{tabular}

$\mathrm{HLI}=$ heat loss index. Data were represented as mean $\pm \mathrm{SD}$. Values with different letters were significant.

Table 2: Blood picture for California and Chinchilla rabbits

\begin{tabular}{|c|c|c|c|c|}
\hline Parameter $\rightarrow$ & California Fema & California $\mathrm{Ma}^{-}$ & Chinchilla Fema ${ }^{-}$ & Chinchilla Mal \\
\hline $\operatorname{RBC}\left(10^{12} / L\right)$ & $4.67 \pm 0.1$ & $4.77 \pm 0.1$ & $4.5 \pm 0.2$ & $4.5 \pm 0.2$ \\
\hline $\mathrm{WBC}\left(10^{9} / \mathrm{L}\right)$ & $5.8 \pm 1.0$ & $5.67 \pm 0.3$ & $6.4 \pm 0.8$ & $5.68 \pm 0.8$ \\
\hline $\operatorname{PLT}\left(10^{9} / \mathrm{L}\right)$ & $467 \pm 55.2$ & $551.33 \pm 46.3$ & $50.8 .78 \pm 80.9$ & $426.6 \pm 96$ \\
\hline HGB (g/dl) & $10.8 \pm 0.4$ & $11.23 \pm 0.4$ & $10.3 \pm 0.5$ & $10.32 \pm 0.5$ \\
\hline LYM $\left(10^{9} / \mathrm{L}\right)$ & $2.5 \pm 0.3$ & $2.23 \pm 0.2$ & $2.87 \pm 0.5$ & $2.32 \pm 0.4$ \\
\hline MONO $\left(10{ }^{9} / \mathrm{L}\right)$ & $0.47 \pm 0.1$ & $0.4 \pm 0.04$ & $0.47 \pm 0.09$ & $0.34 \pm 0.1$ \\
\hline GRAN (10 9/L) & $2.9 \pm 0.6$ & $3.03 \pm 0.1$ & $3.1 \pm 0.4$ & $3.02 \pm 0.3$ \\
\hline HCT (\%) & $32.57 \pm 1.5$ & $29.35 \pm 0.9$ & $29.35 \pm 1.8$ & $28.76 \pm 0.9$ \\
\hline
\end{tabular}

Data were represented as mean \pm SD. Values with different letters were significant.

Fig. 2.
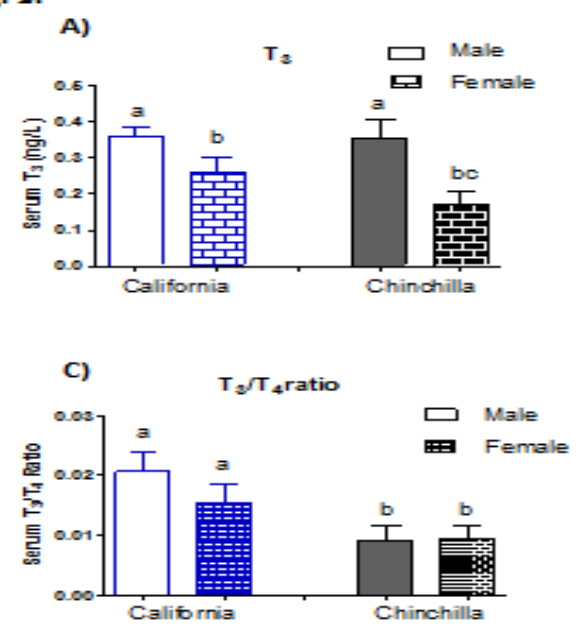
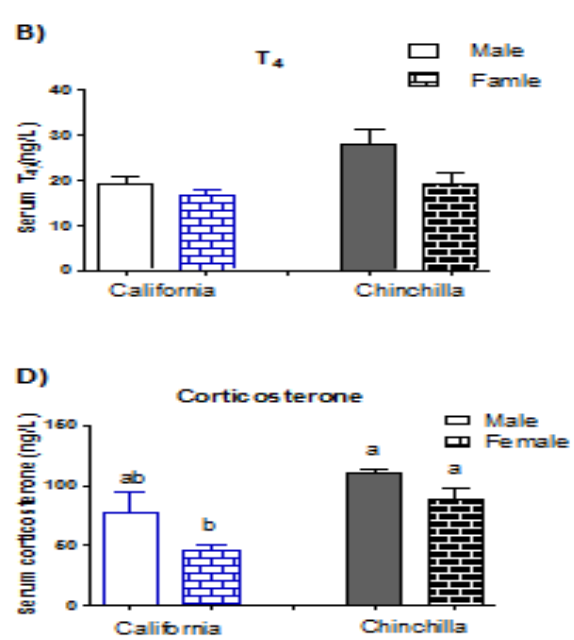

Fig. 2. Serum concentrations of tri-iodothyronine (T3; A) and thyroxine (T4; B), T3/T4 ratio (C) and corticosterone (D) in California and Chinchilla Rabbits. Data were represented as mean \pm SD. 


\section{DISCUSSION}

Rabbit industry is based on providing the community with valuable meat with good quality and unique characteristics. On the other hand, this industry has many threats in Upper Egypt. At the commercial level may breeders make haphazard crosses that may negatively influence heterosis. Under this condition, there is difficulty in starting up portfolios of rabbits records. In this study, we compared two divergent breeds of the rabbit under the environmental condition of Sohag governorate.

In this study, we measured the ambient temperature and relative humidity $(\mathrm{RH})$ continuously by using computed data logger (Fig. 1). Changes in physiological biochemical and hematological values can also be used as indicators of welfare in rabbit breeding (Hoy and Verga, 2006). When fresh blood samples were analyzed by automated cell counter, the hemogram indicated non-significant differences between the two breeds in all measured variables (RBCs, WBCs, platelets, lymphocytes, monocytes and granulocytes and hematocrit values, Table 1). These data were in parallel with a study of Chineke $\boldsymbol{e t}$ al., (2006), in which all genotypes were similar in hemoglobin, erythrocyte number and mean cell volume (MCV). But in another study, some of the hematological variables were affected by the rabbit genotype (Martinec et al., 2012). Our results indicated that there were no breed differences between California and Chinchilla rabbits.

Data of serum hormonal concentrations in both sexes of two breeds showed some within and interbreed variations (Fig. 2). There were sex differences in the serum active form of thyroid hormones tri-iodothyronine $\left(\mathrm{T}_{3}\right)$ and thyroxine $\left(\mathrm{T}_{4}\right)$. Serum $\mathrm{T}_{3}$ concentrations were higher in male than female within two breeds $(P=0.023$, Fig. 2A). Although such tendency for higher concentration in male the female was also lower in thyroxine level $\left(\mathrm{T}_{4}\right)$ but the differences was insignificant $(P>0.5$, Fig. 2B). While calculated $\mathrm{T}_{3} / \mathrm{T}_{4}$ ratios showed distinct differences between breeds (Fig. 2C). California rabbits showed higher $\mathrm{T}_{3} / \mathrm{T}_{4}$ ratio compared to Chinchilla breed $(P=0.026)$. These data may indicate that the metabolic rate was generally higher in male than female; in addition, the conversion from T4 to T3 was higher in California rabbit when compared Chinchilla rabbit.

Corticosterone is the main glucocorticoid in many animal species and birds. It is involved in the regulation of energy, immune reactions, and stress responses (Lattin et al., 2016). The stress hormone (corticosterone) concentrations showed distinct differences between the two breeds.
Corticosterone level was relatively lower in California than Chinchilla $(P<0.001$, Fig. $2 \mathrm{D})$. Our data showed higher concentrations of serum corticosterone than those measured in laboratory rabbits (Cristina et al., 2013). Hence, California breed showed better indices for heat loss, higher metabolic rate, and lower stress hormone level when kept under the same environmental a condition. The overall results may indicate lowered stress level in such breed when compared to Chinchilla.

\section{CONCLUSION}

This study generally refer to the ability of California breed to withstand heat stress is higher than Chinchilla rabbits under the environmental condition of Sohag governorate.

\section{CONFLICT OF INTEREST}

All authors declare the absence of any type of conflict of interest

\section{ACKNOWLEDGMENT}

This work was supported by Grant-in-Aid belonging to the Scientific research Fund of Sohag University, Ministry of Higher Education, Egypt.

\section{REFERENCES}

ABELSON KS, KALLIOKOSKI O, TEILMANN AC, HAU J. 2016. Applicability of Commercially Available ELISA Kits for the Quantification of Faecal Immunoreactive Corticosterone Metabolites in Mice. In Vivo. ;30:739-744. doi: 10.21873/invivo.10989.

CHINEKE, C.A.; OLOGUN, A.G. AND IKEOBI, C.O.N. 2006. Haematological parameters in rabbit breed and crosses in humid tropics. Pakistan J Biol Sci 9: 2102-2106.

HINTON, M.; JONES, D.R.E. AND FESTING, M.F.W. 1982. Hematological findings in healthy and diseased rabbits, a multivariate analysis. Lab Anim 16: 123-129.

HOY, S. AND VERGA, M. 2006. Welfare indicators. In: Maertens L, Coudert P (Eds.) Recent Advances in Rabbit Sciences, ILVO, Melle, Belgium: pp.71-74.

HOY, S. AND VERGA, M. 2006. Welfare indicators. In: Maertens L, Coudert P (Eds.) Recent Advances in Rabbit Sciences, ILVO, Melle, Belgium: pp.71-74.

KUROSAWA, T.; KUSANAGI, M.; YAMASAKI, Y.; SENGA; Y. AND YAMAMOTO, T. 1995. New mutant rabbit strain with hyperocholesterolemia and atherosclerotic lesions produced by serial inbreeding. Lab Anim Sci 45: 385-392.

LATTIN CR, BREUNER CW, MICHAEL ROMERO L. 2016. Does corticosterone regulate the onset of bree ding in free-living birds?: The CORT-Flexibility Hypothesis and six potential mechanisms for priming corticosteroid function. Horm Behav.;78:107-20. 
LEWIS JG, BAGLEY CJ, ELDER PA, BACHMANN AW, TORPY DJ. 2005. Plasma free cortisol fraction reflects levels of functioning corticosteroidbinding globulin. Clin Chim Acta.;359:189-194. doi: 10.1016/j.ccen.2005.03.044.

MAHMOUD, M.E., DOSOKY R.M., AHMED, MM., TAKEWAKI, T. 2011. Estimation of sensible heat loss in capsaicin-desensitized chicken after exposure to disruption of thermal homeostasis. Ass. Univ. Bull. Environ. Res. 14(2) 57-69.

MARTINEC, M. HÄRTLOVÁ, H., CHODOVÁ D, TUMOVA, E. AND FUČÍKOVÁ, A. 2012. Selected hematological and biochemical indicators in different breeds of rabbits ACTA VET. BRNO, 81: 371-375.

NÄÄS, I.A., ROMANINI, C.E.; NEVES, D.P., NASCIMENTO, G.R., AND VERCELLINO, R.A., 2010. Broiler surface temperature distribution of 42-day old chickens. Sci. Agric. 67 (5): 497-502.

PILO A, IERVASI G, VITEK F, FERDEGHINI M, CAZZUOLA F, BIANCHI $R$.1990." Thyroidal and peripheral production of 3,5,3'-triiodothyronine in humans by multicompartmental analysis". The American Journal of Physiology. 258 (4 Pt 1): E715-26.

ROMANOVSKY, A.A. 2007. Thermoregulation: some concepts have changed. functional architecture of the thermoregulatory system. American Journal of Physiology, Regulatory, Integrative and Comparative Physiology 292 (1), R37-R46.

STEINER, A.A. AND BRANCO, L.G. 2002. Hypoxiainduced anapyrexia: implications and putative mediators. Annual Review of Physiology 64, 263288.
How to cite this article:

Gehad Seddik; Ahmed A. Aboughaba; Fatma A. Mahmoud; Doaa Salman and Motamed E. Mahmoud, 2019. A Comparative Study on Biochemical Parameters for Mature California and Chinchilla Rabbits in Sohag Governorate. Journal of Applied Veterinary Sciences, 4(1): 43- 47. DOI : https://dx.doi.org/10.21608/javs.2019.62677 